\title{
CeLULAR NA ESCOLA: POLÍTICAS, USOS E DESAFIOS PEDAGÓGICOS*
}

\author{
Lívia da Silva Neiva Martin \\ Universidade Estadual de Goiás, Anápolis, Goiás, Brasil \\ Mirza Seabra Toschi \\ Universidade Estadual de Goiás, Anápolis, Goiás, Brasil
}

\begin{abstract}
REsUmo: Este estudo teve como objetivo geral identificar e analisar quem e quais são os atores escolares que usam o celular na escola. Buscou, ainda, identificar quais mudanças ocorreram e ocorrem com o uso do celular na escola na perspectiva de conhecer as alterações provocadas nas atividades pedagógicas de escolas municipais e estaduais de uma cidade de médio porte. Com abordagem qualitativa, foram realizadas observações de diferentes situações de uso do celular na escola, relatos espontâneos dos pesquisados, anotados em protocolos de registro, e aplicação de questionário para os estudantes. Os celulares estão na escola e discutir formas de incorporação e de usos intencionais para esse contexto é importante, pois é parte da cultura dos sujeitos que ali frequentam. No entanto, para que se transformem em elementos concretos de compromisso profissional, cultural, social e político, precisa-se de gestores capacitados, professores bem formados e escolas em condições adequadas.
\end{abstract}

Palavras-chave: Escola. Celular. Educação.

\section{INTRODUÇÃO}

Apesar da existência de leis em alguns estados que proíbem o uso de celular no ambiente da escola, é fácil identificar seu uso nas escolas por estudantes, professores e funcionários. A teledensidade aumenta a cada mês, como também os celulares se aperfeiçoam, permitem acesso à internet e a

\footnotetext{
* Artigo recebido em 7/3/2014 e aprovado em 5/5/2014.
} 
eles convergem diversas mídias. A conexão móvel amplia as possibilidades interativas, levando a questionamentos sobre o que isso está gerando no ambiente escolar. Quem usa o celular na escola? Como está sendo feito esse uso? Para que se usa celular na escola? Há normas que instituem seu uso? Quais mudanças ocorrem na escola e nas suas atividades pedagógicas? Quais os principais desafios que sua presença na escola traz? É isso que se pretendeu investigar em escolas de ensino fundamental e de nível médio em Anápolis. Para essa pesquisa, foram feitas observações de diferentes situações de uso do celular na escola, anotadas em protocolos de registro. Aconteceram também conversas informais, ou seja, relatos espontâneos dos pesquisados e foram geradas fotos e vídeos de estudantes usando os celulares.

São poucos os estudos sobre a temática e praticamente ausentes nas pesquisas das universidades, o que justificou o desenvolvimento da investigação, a fim de que se contribua com uma reflexão mais rigorosa sobre essa questão atual e a cada dia mais presente na vida cotidiana, em especial na dos mais jovens.

\section{Celular na escola - Perguntas Que surgem}

Este estudo teve como objetivo geral identificar, analisar e interpretar quem e quais são os atores escolares (alunos, professores e funcionários) que usam o celular na escola, destacando como usam, a frequência de uso e para qual fim. Buscou, ainda, identificar quais mudanças ocorreram e ocorrem na escola na perspectiva de conhecer as alterações provocadas nas atividades pedagógicas de escolas municipais e estaduais de uma cidade de médio porte.

Como objetivo específico, pretendeu-se conhecer as compreensões que os agentes educativos das escolas pesquisadas têm sobre o uso do celular na escola, na perspectiva educativa, buscando identificar se compreendem a potencialidade de o celular ser um meio de formação escolar. Seria mesmo a escola um espaço híbrido? Quais elementos permitirão fazer essa afirmação?

\section{COMO OS DADOS FORAM COLETADOS}

Esta pesquisa teve abordagem qualitativa. Esse tipo de metodologia se justifica por ser um estudo que busca conhecer a escola como espaço social. Sob a ótica de Lüdke e André (1986), na pesquisa qualitativa, "o pesquisador é o instrumento principal na coleta e na análise dos dados. Os dados são mediados pelo instrumento humano, o pesquisador" (p. 28). A presença constante dos pesquisadores no campo de investigação para coleta de dados possibilita uma revisão, se necessário, das questões orientadoras do estudo. 
O ambiente natural é uma característica básica da pesquisa qualitativa e, no caso desse estudo, a escola foi a fonte direta de dados, promovendo o envolvimento direto com o campo de pesquisa, quatro escolas de educação básica. Pelo fato de o pesquisador ser o principal instrumento, a equipe de coleta de dados fez observações por quase cem horas, de forma a ter um contato direto e duradouro com a situação a ser estudada.

Nos seis primeiros meses de estudo, realizamos observações em duas escolas da rede municipal e duas escolas da rede estadual. Por se tratar de uma mídia proibida por lei, os critérios para a seleção das escolas aconteceram com apoio e o aval da Secretaria Municipal de Educação e da Secretaria Estadual de Educação, bem como a autorização das diretoras das unidades escolares em questão.

Na rede municipal de ensino, foram observadas seis turmas do $6^{\circ}$ ano, cinco turmas do $7^{\circ}$ ano e quatro turmas do $8^{\circ}$ ano, totalizando, assim, 15 turmas observadas num período de quatro semanas e 48 horas de aula observadas. Na rede estadual de ensino, foram observadas 11 turmas do $1^{\circ}$ ano, seis turmas do $2^{\circ}$ ano, totalizando 17 turmas observadas num período de cinco semanas e 48 horas de aula observadas. Preenchemos Protocolos de Registro das observações e aproveitamos os recursos de nossos próprios telefones celulares para registrar também em foto e vídeo, com as devidas autorizações. Estivemos atentas às orientações de Lüdke e André (1986) sobre o pesquisador ser o instrumento principal na coleta e análise dos dados: "Os dados são mediados pelo instrumento humano, o pesquisador" (p. 28). Por isso, nossa presença no campo de investigação para coleta de dados foi planejada e também foi constante nossa preocupação em observar e registrar pequenas ações, aparentemente desinteressadas, atitudes e expressões que fizeram parte das ações dos sujeitos das escolas pesquisadas.

Os referenciais da pesquisa qualitativa têm sido adotados tanto no campo da educação quanto da comunicação, pois ambos propiciam a apreensão rigorosa do objeto, levando em conta o contexto em que ele está inserido, bem como desvelam as múltiplas dimensões presentes na realidade empírica investigada, exigindo diferentes fontes de informações, utilizando instrumentos variados. Para Lüdke e André (1989), “o que esse tipo de pesquisa visa é a descoberta de novos conceitos, novas relações, novas formas de entendimento da realidade" (p. 30). A percepção dos pesquisados e o significado que dão ao fato investigado é respeitado e valorizado na descrição dos dados.

Somente ao final de cada semana de observação é que nos identificávamos, para os alunos, como pesquisadoras e com o tema da pesquisa. Até então, éramos apresentadas pela coordenação como pesquisadoras da 
universidade, mas sem identificação do tema de estudo. Durante a aplicação do questionário, nós nos identificamos, explicamos sobre a pesquisa e pedíamos a colaboração dos estudantes, respondendo ao questionário.

O questionário foi composto por cinco questões objetivas e duas questões subjetivas com a finalidade de identificar a posse, a idade de obtenção do primeiro celular, as principais funcionalidades utilizadas, se os estudantes consideram ou não o celular como fator de distração e a opinião deles sobre a proibição dos aparelhos na escola. Foram aplicadas para todas as séries finais do ensino fundamental e para todas as turmas de $1^{\circ} \mathrm{e} 2^{\circ}$ anos do ensino médio. No total, 668 estudantes do $1^{\circ} \mathrm{e} 2^{\circ}$ anos das duas escolas de ensino médio responderam ao questionário, dos quais 639 (96\%) afirmaram possuir um aparelho de telefone celular ou smartphone. Somando as duas escolas de ensino fundamental, 354 estudantes dos anos finais $\left(6^{\circ}, 7^{\circ}\right.$ e $\left.8^{\circ}\right)$ responderam ao questionário, dos quais 315 (89\%) afirmaram possuir um aparelho de telefone celular ou smartphone. Isso totalizou a aplicação de mais de mil questionários.

\section{REGULAÇÃO E CONTROLE BASEADOS EM LEIS E ACORDOS PUNITIVOS}

Após passarmos por um processo de revisão sistemática', iniciamos uma busca sobre as leis existentes em todo o território brasileiro que proíbem o uso dos aparelhos celulares nas escolas. Encontramos sete leis que apontam sobre o assunto, sendo uma federal, cinco estaduais e uma municipal.

No âmbito federal, temos o Projeto de Lei n. 2.806/2011, de autoria do deputado Márcio Macedo (PT/SE), que, até o momento desta redação de acordo com o sítio www.camara.gov.br - estava "aguardando parecer na Comissão de Educação" e que trata da proibição de aparelhos eletrônicos portáteis nas salas de aula dos estabelecimentos de educação básica e superior, salvo o que seja utilizado nas atividades pedagógicas². Esse projeto de lei apresenta a seguinte justificativa:

Venho por meio deste projeto de lei reapresentar a matéria, aproveitando os aperfeiçoamentos que ela recebeu na Comissão de Educação e Cultura. Na discussão do Projeto, nessa Comissão, em 2009, concluiu-se que, "para preservar a essência do ambiente pedagógico, cabe a extensão da proibição de uso em sala de aula a todos os equipamentos eletrônicos portáteis que desviam a atenção do aluno do trabalho didático desenvolvido pelo professor." Além disso, argumentou-se que "a utilização desses equipamentos em sala de aula é ainda mais frequente entre os alunos das instituições de ensino superior que na educação básica, motivo pelo qual se acordou pela ampliação da abrangência da proposta àquele nível de ensino". (PL 2.806/2011) 
Esse texto foi substitutivo ao Projeto de Lei n. 2.246/2007, do deputado Pompeo de Mattos (PDT-RS), que foi arquivado em janeiro de 2011. Na proposta original, o texto proibia o uso apenas dos celulares e somente por parte dos alunos das escolas públicas. O texto aprovado (PL 2.806/2011) expande a proibição para qualquer aparelho eletrônico portátil, de alunos e professores, nas salas de aula das escolas de educação básica e superior de todo o país. E, em parágrafo único, admite o uso "desde que inseridos no desenvolvimento de atividades didático-pedagógicas e devidamente autorizados pelos docentes ou corpo gestor"(PL 2.806/2001, parágrafo único).

O que seria preciso fazer para "preservar a essência do ambiente pedagógico"tal como proposto no PL 2.806/2011? Promulgar leis é suficiente? Começamos a pensar que, talvez, seja preciso reiniciar o debate sobre os desafios que as diferentes tecnologias estão impondo à educação escolar, por uma clarificação do papel da escola e dos professores, bem como o reconhecimento das muitas instituições da sociedade que promovem a educação na contemporaneidade (LIBÂNEO, 2000, p. 7). A análise dos motivos subjacentes à atividade docente é condição sine qua non para a compreensão dos desdobramentos das ações mediadas pela tecnologia (DURAN, 2010, p. 18), afinal, a escola não pode tudo (NÓVOA, 2009) e não detém, sozinha, o monopólio do saber (LIBÂNEO, 2000 e 2008).

Como um contraponto e na contramão da visão corrente, entendemos que a utilização das TIC pode ou não encertar certos processos de desenvolvimento, a depender das mediações humanas que envolvem as práticas de letramento digital. Os usos diversos dos recursos tecnológicos podem instilar processos de desenvolvimento plurais, razão pela qual é preciso considerar os sujeitos, os contextos, as práticas e os motivos que regem a utilização das TIC. (DURAN, 2010, p. 18)

No contrafluxo da promulgação dessas leis e decretos, temos a ampla aceitação do telefone móvel pela população brasileira. De acordo com a Agência Nacional de Telecomunicações (Anatel), o Brasil iniciou o ano de 2013 com mais de 263 milhões de linhas ativas, ultrapassando a marca de um celular por habitante. Dados que refletem na realidade observada por nós, nessas quatro escolas. Professores, diretores, faxineiras, administradoras, enfim, as pessoas envolvidas nas instituições visitadas portavam celulares; às vezes, mais de um aparelho. Independentemente da idade, independentemente de ter maior ou menor poder econômico. Apesar de encontrarmos, em todas as escolas visitadas, o texto da lei estadual de proibição ao uso do celular anexado na entrada da escola e em locais visíveis, como murais de avisos, essa tecnologia foi visivelmente detectada nas mãos, no bolso da calça jeans, 
dentro da bolsinha de lápis, no jaleco branco que alguns professores trajavam, na mesa da diretora. Apesar de leis e regimentos de proibição, o celular está presente na escola.

Durante a fase exploratória da pesquisa, uma das diretoras apresentou-nos uma cópia do documento intitulado "Carta de Compromissos", que foi elaborado em conjunto pelas secretarias estaduais e municipais de Educação, por representantes do Ministério Público, da Polícia Militar, da Polícia Civil, do Conselho Tutelar, gestores das escolas estaduais e municipais, bem como representante dos alunos das redes de ensino.

Com o propósito de resgatar valores, conforme relataram os gestores das escolas, na busca de uma cultura de paz no ambiente escolar, representantes de professores, pais, alunos, funcionários e gestores de todas as unidades escolares municipais e estaduais, bem como representantes da Polícia Militar, Polícia Civil, Conselho Tutelar, Divisão de Fiscalização e Postura e do Ministério Público, participaram de um seminário com o objetivo de reeditar a "Carta de Intenções", assinada, em 2007, por autoridades municipais. Com o nome de "Carta de Intenções", os representantes das entidades supracitadas reeditaram esse documento, que passou a ser denominado "Carta de Compromissos", assinada no dia 28 de junho de 2012, em cerimônia realizada no auditório do Senai.

A carta apresenta uma série de compromissos assumidos pelas instituições para a construção de uma cultura de paz nas escolas. Em síntese, o documento apresenta preocupação com a divulgação e o cumprimento do regimento escolar; participação da família nas atividades dos filhos; combate ao uso e tráfico de drogas; segurança a partir da presença da Patrulha Escolar da Polícia Militar em todos os turnos de funcionamento das unidades escolares; ações para coibir a indisciplina e a violência; ciência dos pais quanto às suas obrigações em relação à educação dos filhos, incluindo a obrigação de levá-los ao médico. Destacamos aqui o compromisso 3, que envolve nossa temática:

3. Proibir, nas dependências da Escola, o uso do boné, shorts curtos, minissaias, blusas curtas, decotadas e transparentes bem como alteração no uniforme (com exceção dos concluintes), uso do celular e equipamentos tecnológicos não compatíveis com as atividades pedagógicas, bem como proibir o uso do cigarro nas dependências da escola para funcionários e alunos.

Julgamos esse documento interessante por reunir agentes educativos de diferentes instituições. Entendemos que, com ele, a escola reconhece que a educação, da forma como tem sido exigida, não é papel só dela e que encontraram nas instituições como Ministério Público, Conselho Tutelar, 
Polícia Civil e Polícia Militar auxílio para lidar com as questões de violência, drogas e desestruturação familiar. Acreditamos que seja mesmo preciso reunir todos os agentes educativos da contemporaneidade na construção de uma cultura de paz. Entretanto, é preciso reconhecer e cobrar também das muitas instituições da sociedade que promovem a educação na contemporaneidade, tais como família, igrejas de todas as representações de fé, Organizações Não Governamentais, grandes empresas de comunicação que determinam a programação da televisão, assim como as empresas que desenvolvem jogos eletrônicos, entre tantas outras instituições que também contribuem para a educação plena do ser humano. Mas o mais importante de tudo isso é a desresponsabilização da escola em relação aos seus compromissos educativos. Com a entrada na escola da Patrulha Escolar para cuidar da disciplina, a escola abre mão do seu papel de educadora e minimiza tanto o conceito de cultura de paz nas escolas e do próprio conceito do que seja disciplina na escola. Disciplina intelectual, despertando nos estudantes o gosto pelo estudo, por meio dos desafios pedagógicos, é o principal papel da escola, a essência do trabalho pedagógico, a como se refere a justificativa da lei federal.

Essa "Carta de Compromissos" é colada no caderno de todos os estudantes e usada como instrumento de controle para a não utilização do celular em sala de aula. O que observamos foi a seguinte dinâmica: a professora recolhe o celular do estudante em sala de aula e encaminha para a diretora ou coordenadora pedagógica. Somente os pais ou responsáveis podem ir buscá-lo. Quando os pais vão à escola, eles ouvem da equipe gestora sobre a proibição e um alerta de que, da próxima vez, ele será encaminhado para o Ouvidor e Agente do Juizado da Secretaria Municipal, e, no caso do ensino médio, encaminhado para o Conselho Tutelar. Ou seja, a tolerância em relação ao uso do celular na sala de aula é zero, o que, consequentemente, impede seu uso de maneira pedagógica.

A questão dos usos dos celulares parece estar fortemente vinculada à questão do controle sobre o que se passa dentro da escola. Em entrevista, na fase de seleção das escolas, com cinco diretoras de escolas municipais e duas de escolas estaduais, as gestoras se mostraram incomodadas pelo não controle dos estudantes, conversando diretamente entre eles, sem intermediários, configurando práticas de registro e de compartilhamento em foto, microtexto e vídeo, de todo tipo de sentimento humano. A troca direta entre os próprios alunos, com vazão a todo tipo de expressão, e destaque para os casos de sexualidade, brigas e drogas, inicialmente foi o realce na fala dessas diretoras. Pareceu-nos que a proibição ante o uso do celular está ligada à responsabilidade da gestão sobre o que acontece nesse espaço 
formal público: as repercussões que certos conteúdos podem trazer para a imagem daquela instituição educativa e a satisfação devida aos pais sobre o que fazem (aluno que pratica a ação comunicativa de compartilhar) e o que sofrem (alunos que são vítimas do conteúdo compartilhado) seus filhos quando sob a tutela dessa instituição.

A loucura, a violência, a desestruturação familiar, as questões de gênero e as diferenças de fé religiosa sempre existiram. Atualmente, no entanto, com o celular há a possibilidade do registro, do compartilhamento em rede e da evidência imediata. Os desdobramentos dos casos de compartilhamento de imagens como nu frontal de uma estudante ou convite para uma briga na porta da escola (relatos das diretoras), entre outros casos de comportamento, foram frequentes no depoimento para justificar a proibição do aparelho. $O$ chamamento de atenção dos pais, o encaminhamento para o Conselho Tutelar e até mesmo o pedido de socorro para a Polícia Civil foram soluções encontradas para "disciplinar" os usos do celular na escola.

Embora uma diretora tenha dito acreditar que o que falta é a "conscientização para o uso, já que não conseguimos controlar a não presença do aparelho na escola", nenhuma das entrevistadas citou a promoção de palestras, debates ou espaços de esclarecimentos, de conversas sobre as questões que estão emergindo pelos usos desse aparelho na escola ou até mesmo uma tentativa de negociar os usos que são feitos do celular na escola. Faltou diálogo que tentasse conscientizar sobre as consequências dos tipos de registro e de compartilhamento que os estudantes fazem.

Pelos primeiros contatos iniciais com essas diretoras, as questões de comportamento sobressaíram ante qualquer possibilidade de uso com intencionalidade pedagógica. Roubo, furto, tráfico de drogas, prostituição, fotos sensuais foram frequentes nas reclamações quanto aos usos do celular e da internet na escola. Como observa Santaella (2010), as idiossincrasias humanas registradas, compartilhadas e reveladas instantaneamente, talvez, sejam o desafio maior da era da mobilidade. E, para a escola, instituição social importante, mas ainda permeada de muito controle e regulação, o que foge ao seu monitoramento pode se tornar um grande desafio.

Também não pudemos deixar de registrar uma ambivalência entre os papéis de gestora e mãe, apresentados pelas entrevistadas. Enquanto gestoras posicionaram-se contra a presença do celular na escola, entretanto, as sete diretoras, quando se colocaram na posição de mãe, disseram ser imprescindível que seus filhos levem seus celulares, pois elas precisam saber onde encontrá-los, o que estão fazendo, enfim, monitorá-los. E elas estenderam essas preocupações às professoras. Uma diretora contou que a maioria dos profissionais de educação que trabalham naquela unidade escolar 
constitui-se de mulheres casadas e com filhos pequenos. "Elas precisam saber sobre suas crianças para trabalharem com tranquilidade. Então, é permitido que levem seus celulares para a sala de aula, desde que atendam somente em casos de emergência e que o façam fora da sala".

O celular permite a relação familiar a distância. Essa tecnologia também se tornou um meio de comunicação que facilita a coordenação das atividades da família. Profissionais da educação e mães podem continuar em contato direto e constante com suas crianças mesmo no período em que se encontram trabalhando na escola. Para Caron e Caronia (2005), a família contemporânea parece ter encontrado uma tecnologia que permite "o exercício do controle e da responsabilidade familiar, de um lado, e a independência e autonomia comunicativa das suas próprias crianças de outro" (p. 7). Para Dominique Wolton (2006), o telefone celular simboliza a onipresença do outro. Com o celular próximo, é como se o contato com o filho estivesse sempre ali com ela, o aparelho representa a possibilidade de saber notícias do filho em qualquer lugar, a qualquer hora.

A presença do celular na escola apresenta desafios comportamentais, técnicos, administrativos, comunicacionais e pedagógicos que importa resolver dentro do contexto real de cada unidade escolar. O que nos remete à complexidade de cada contexto escolar. São muitos fatores que podem interferir na relação didático-pedagógica ou de gestão de uma escola pública. Para Duran (2010), não existem seres humanos à margem da História; todos nós, de uma forma ou de outra, estamos relativa e simultaneamente incluídos e excluídos nesse sistema capitalista e cada vez mais tecnológico. Essa constatação nos obriga a desviar o foco da dicotomia e das soluções monolíticas. É preciso considerar cada sujeito, cada contexto, cada bairro, cada escola. Muitas transformações esperadas simplesmente não acontecem, enquanto outras podem se manifestar de modo imprevisível e plural. Em cada escola visitada, as observações foram únicas, porque cada escola representou um contexto, um público e profissionais diferentes. Não há regra, há pessoas. E as pessoas são o que são, únicas; para cada uma delas há uma história, um caso distinto, uma necessidade específica, um registro diferente captado ou não pelo celular.

\section{ApRoveitAMENTO EM CONTEXTO ESCOLAR DOS DISPOSITIVOS MÓVEIS}

Tomemos como exemplo inicial as aulas de Educação Física, observadas em uma das escolas municipais, em que o professor permitia o uso do aparelho celular na quadra de esportes, alegando ser uma boa maneira de os alunos poderem aproveitar os recursos do telefone móvel que portavam 
consigo. Em sua aula, os alunos utilizavam para dançar, montar coreografias, cantar em grupos, e alguns ficavam sozinhos, ouvindo músicas com fones de ouvido. Em todas as observações que realizamos na quadra de esportes, os alunos estavam utilizando o aparelho. Já nas salas de aula, observamos estudantes copiando a matéria do quadro ao mesmo tempo em que mexiam em seus telefones celulares. Algumas vezes, quando o professor se ausentava da sala de aula, os estudantes aproveitavam para tirar fotos, gravar vídeos ou compartilhar os fones de ouvido. Observamos também alguns alunos que fizeram uso de seus telefones celulares como auxiliadores no processo de aprendizagem, por exemplo, com o uso da calculadora e para baixar livros solicitados pelos professores.

O recreio era o palco do desfile de vários eletrônicos - celulares, $\mathrm{mp} 3$ players, fones de ouvido, tablets, netbooks e acessórios, como a diversidade de capinhas para celulares. O fone de ouvido era frequentemente dividido entre o proprietário e outro colega. O fascínio por esses objetos foi visível. Nossa sensação foi a de que a posse de um celular assegura o pertencimento a um grupo: como se fizesse parte da identidade da juventude contemporânea. Para além da manifestação de um consumismo, pareceu-nos ser parte da constituição do que é ser jovem hoje, tal como relatou a pesquisadora carioca Miriam Leite, em suas reflexões sobre o impacto dos usos dos dispositivos móveis no cotidiano escolar:

Entre os objetos que identificam o adolescente de hoje, os eletrônicos se destacam por marcar forte diferença em relação às gerações anteriores. Usuários diretos ou não, nossos adolescentes dialogam com discursos da cultura do computador e da internet, do videogame e do celular. Se é certo que a midiatização e a espetacularização da vida pública e privada já marcavam as últimas gerações, a interconectividade, por outro, pertence aos tempos atuais. (LEITE, 2009, p. 126)

Em geral, o que conseguimos perceber foi que os professores não têm com o celular a mesma relação que os estudantes, embora, em uma das escolas de ensino médio pesquisada, tivesse um número considerável de professores bem jovens (recém-formados). Os professores não apresentaram o uso desses dispositivos em sala de aula. Na hora do recreio, na sala dos professores, percebemos a presença do aparelho, alguns professores demonstraram intimidade e usabilidade, enquanto outros declararam fazer uso apenas para ligações e SMS, em momentos adequados.

Numa determinada aula de Química, na qual a professora estava trabalhando um conteúdo que precisava da realização de operações com números decimais, uma aluna usou a calculadora do celular e percebeu que 
a conta feita pela professora (feita sem o uso de calculadora) estava errada. Então, com muita discrição, chamou a professora à sua cadeira e mostrou em seu celular a conta que fez. A professora duvidou ter errado, mas foi convencida pela demonstração da estudante em seu celular e, então, corrigiu no quadro.

Se forem espertos, os educadores descobrirão como oferecer seu produto de uma maneira adaptada à vida digital - e aos celulares - de seus alunos. Em vez de gastarem energia, lutando contra o sistema de distribuição preferido dos estudantes, trabalharão para assegurar que eles extraiam o máximo de entendimento e benefício da enorme quantidade de aprendizado via celular de que, sem dúvida, tirarão vantagem em breve. (PRENSKY, 2010, p. 185)

Marc Prensky (2010), escritor e criador dos termos "nativos digitais"e "imigrantes digitais", foi um dos primeiros a propor o uso do celular em sala de aula. A lógica de Prensky é: se os estudantes já têm o dispositivo móvel e o levam para a escola, por que não aproveitar para tirar vantagem educacional? Para isso, seria preciso enxergar o celular como uma tecnologia que vai além da capacidade de comunicação, mas envolve também a evolução dos microchips, microcomputadores, microcâmeras de vídeo e foto, microtexto e os jogos eletrônicos. Para esse autor, os celulares sofisticados possuem o poder computacional de um computador de mesa de meados dos anos de 1990, consumindo apenas um centésimo da energia e ocupando menos de um centésimo do espaço (PRENSKY, 2010, p. 185).

Em sua tese de doutoramento pelo Instituto de Educação da Universidade do Minho, Braga, Portugal, em Ciências da Educação, na Especialidade de Tecnologia Educativa e intitulada "Apropriação do telemóvel como ferramenta de mediação em Mobile Learning. Estudos de caso em contexto educativo", Adelina Moura (2010) concluiu que os 78 alunos de ensino médio e profissional pesquisados aceitaram usar seus próprios aparelhos de telefone celular e os incorporaram naturalmente em suas práticas de estudo. Para essa pesquisadora, o celular usado como ferramenta mediadora de aprendizagem possibilitou tirar dúvidas e aprender quando era mais conveniente, permitindo um contato permanente com os conteúdos curriculares, aumentando a motivação do aluno pela disciplina, no caso de seu estudo, Português e Francês, e aperfeiçoando a leitura em língua estrangeira - nesse caso, o Francês.

Moura (2010) considera que a questão não é a possibilidade de o celular substituir outros instrumentos de aprendizagem, mas de integrá-lo como parte de uma cultura social e uma ferramenta com grande potencial para ajudar a desenvolver competências do século XXI, dependendo de como o utilizarmos (MOURA, 2010, p. 4). O tema central na pesquisa de Moura (2010) 
é o aproveitamento em contexto escolar dos dispositivos que os sujeitos da escola usam e levam consigo para todo lado. É uma tecnologia pessoal e amigável, fácil de usar, que grande parte das pessoas usa constantemente em todos os momentos da vida e numa variedade de situações diferentes. Porém, essa tecnologia não é aproveitada para ensinar e aprender (MOURA, 2010, p. 9). Nas duas escolas em que ocorreu sua investigação, o uso do celular estava proibido, e isso, como também a dificuldade dos agentes escolares em trabalhar com um dispositivo tão novo para as atividades pedagógicas, impediu seu uso de forma educativa. Fica também a perplexidade de como se proíbe celulares nas escolas e se faz lei para isso, quando a política educacional federal distribui laptops e tablets nas escolas.

\section{A ESCOLA PASSA A SER ESPAÇO HÍBRIDO}

O tempo na escola tradicional é determinado pelo relógio e o espaço é sempre delimitado física e geograficamente. Na era das conexões, o tempo e o espaço estão integrados, uma vez que as mídias móveis permitem uma conversação constante (a comunicação no sentido de interação), em qualquer hora e em qualquer lugar. O real, o virtual, o tempo e o espaço estão juntos, hibridizados, são ubíquos. E, nesse tempo híbrido, de possível comunicação e interação constante, percebemos "ampliada a integração de linguagens, num sistema que envolve recursos da informática, da televisão, do rádio, do telefone, incrementando uma nova lógica de acesso e relacionamento com a informação" (BARROS, 2000, p. 94) que impactam também uma nova dinâmica da formação da cultura.

Essa possibilidade de comunicação contínua dos usuários que carregam aparelhos portáteis e móveis de comunicação está integrando os espaços físicos e digitais. No caso da escola, os estudantes comunicam, transmitem e compartilham informações para qualquer pessoa, ao mesmo tempo em que estão sentados e enfileirados nas carteiras da sala de aula. Por exemplo, o estudante da $6^{a}$ série, em sala de aula, pode se fazer presente na sala de aula da $8^{a}$ série, por meio das mensagens multimidiáticas e trocas instantaneamente entre eles, superando as barreiras físicas que, nesse caso, seriam as paredes que separam uma sala de aula da outra. Fisicamente, os alunos estavam ali na escola, na sala de aula, mas simultaneamente interconectados com outras pessoas presentes ou não no mesmo espaço físico que eles. O que nos remete ao conceito de espaços híbridos de Souza e Silva (2006). Para essa pesquisadora, espaços híbridos são "espaços móveis, conectados e sociais, criados pela constante movimentação de usuários que carregam aparelhos portáteis de comunicação continuamente conectados à internet e a outros 
usuários" (p. 24). A mudança de interface transforma as relações sociais que medeia, mas também os espaços onde está inserida.

O conceito de interface homem-máquina tradicionalmente define uma relação comunicacional entre um ser humano e um computador. Neste caso, o papel da interface é de traduzir informação digital do computador para o ser humano, de modo a torná-lo compreensível para nós. Dentro desse contexto, o conceito proposto de "interface social" define um meio digital que intermedeia relações entre dois ou mais usuários. Assim, as inferfaces sociais não apenas re-definem relações comunicacionais, mas também re-conceitualizam o espaço em que essas interações ocorrem. (SOUZA \& SILVA, 2006, p. 23)

Trazendo isso para a realidade observada nas escolas, podemos dizer que os usos observados do celular em sala de aula e nos demais espaços das instituições visitadas permitem a continuidade das relações comunicacionais acontecidas na família, no trabalho, na igreja ou na própria escola. Dessa forma, temos presente, no espaço escolar, todos estes "ausentes": o pai não está fisicamente na escola, mas continua a monitorar a filha pelo celular; o pastor não está fisicamente na escola, mas no aplicativo da Bíblia que foi baixado para o aparelho celular; a amiga que está em uma série diferente, ou até mesmo em escola diferente, é companhia em qualquer espaço físico, principalmente por meio de aplicativos de instant messaging (SMS, Gtalk, Whatsapp).

Então, as relações comunicacionais não são rompidas, não são desconectadas, elas se fazem presentes também nesse espaço que deveria ser exclusivo do aprendizado, mas que é também, e cada vez mais, de continuidade das relações familiares e sociais. Assim, o celular é caracterizado como interface social, pois é um meio digital intermediando relações entre dois ou mais usuários, presentes ou não fisicamente na escola, re-definindo relações comunicacionais e re-conceitualizando o espaço em que essas interações acontecem.

As mídias móveis estão, assim, transformando as salas de aula em espaços híbridos, nos quais convivem a realidade concreta material e a realidade virtual do ciberespaço. $O$ dispositivo celular, que é móvel, possibilita conviver simultaneamente real e virtual. Segundo Toschi (2011), os celulares permitem o acesso à internet em espaços públicos, como a escola, e, segundo Souza e Silva (2006), a mudança de interface transforma as relações sociais que medeia, mas também os espaços onde está embutida. A escola não é mais a mesma depois do celular. 


\section{Conclusões}

Pesquisar sobre os usos do celular na escola é também pesquisar a própria escola, o dia a dia, os profissionais que trabalham ali, as exigências, as cobranças das instâncias municipais, estaduais e federais. A realidade observada durante nossa pesquisa sobre esse tema obrigou-nos a retornar para as questões sobre a formação de professores e os objetivos e funções da escola pública. No exercício de observar e descrever o dia a dia das quatro escolas pesquisadas, encontramos fragilidades de tantas ordens: carências na infraestrutura arquitetônica; absenteísmo do quadro docente; dupla ou tripla jornada de alguns professores; rígidos procedimentos burocráticos; avaliações pré-estabelecidas pelo governo estadual e federal; didática centrada no copiar do quadro-negro para o caderno; foco exclusivo da necessidade de aprender para passar nas provas do colégio, no Enem ou no vestibular; valorização da memória para passar de ano ou nas diversas avaliações; carência cultural e científica de alguns dos profissionais; mistura da ordem religiosa no agir pedagógico docente.

Fatores externos e internos condicionam os objetivos dessa instituição formal e pública. Problemas enraizados uns nos outros se fazem presentes na vida diária da escola. Além dos supracitados, podemos acrescentar as questões sociais, de gênero, econômicas, culturais, de saúde, de violência, das novas configurações das famílias (também precisa ser dita no plural - dois pais, duas mães, pai e madrasta, mãe e padrasto, mãe e avó, somente avó) e do acesso e da posse às "novas tecnologias", entre outras questões que afetam o processo interativo e comunicacional de uma sala de aula, transformando a dimensão da relação professor-aluno e que, por vezes, acabam por confundir a finalidade dessa instituição.

Essa escola, cobrada e avaliada permanentemente, com esse quadro de profissionais, tem condições de negociar os usos dos celulares para uma intencionalidade pedagógica? Nessa escola real, burocrática, fechada, controlada e controladora, com profissionais mal remunerados, alguns em dupla ou tripla jornada, alguns com descaso, outros cansados, doentes, com desvio de área ou com pouco domínio da área da ciência em que foi escalado para ministrar aulas, cobrados e avaliados constantemente, dão conta de mais essa tarefa? O que se convencionou intitular de tecnologias da informação e comunicação ou novas mídias, quando em contexto formal de educação, são agentes complicadores do processo ensino-aprendizagem, pois exigem uma formação docente mais complexa e uma escola centrada nos processos de ensino e aprendizagem.

Na perspectiva de Pretto (2011), pensar ações para o desafio de educar na era digital pressupõe pensar em educações, no plural, com bases bem diferenciadas das atuais, com professores fortalecidos. 
O professor tem que ser valorizado enquanto elemento que possa articular essas diversas instâncias na produção do conhecimento e das diferenças trazidas pelos seus alunos. Assim, e somente assim, com o professor retomando o seu papel de liderança científica, cultural, ética, a escola pode assumir a condição de se constituir num efetivo espaço coletivo de culturas e conhecimentos. (PRETTO, 2011, p. 114)

Essa percepção encontra eco nas análises de Libâneo (2008, p. 13), que acredita que a formação de professores possa incluir a apropriação das tecnologias, desde que estejam garantidos uma formação cultural sólida, o domínio dos conteúdos e uma visão crítica do seu trabalho e da sociedade. Também para Nóvoa (2009, p. 13), os professores reaparecem, no século XXI, como elementos insubstituíveis não só na promoção das aprendizagens, mas também no desenvolvimento de métodos apropriados de utilização das novas tecnologias. Os celulares estão na escola e outras mídias também. Discutir formas de incorporação e de usos intencionais para esse contexto é importante, pois é parte da cultura dos sujeitos que ali frequentam. No entanto, para que se transformem em elementos concretos de compromisso profissional, cultural, social e político, precisam de outras condições objetivas, tanto da instituição quanto dos profissionais. Dificilmente a incorporação intencional e educativa de qualquer mídia acontecerá se não se alterarem as condições existentes nas escolas e as políticas públicas em relação aos professores (NÓVOA, 2009, p. 21).

\section{CELL PHONES IN THE SCHOOL: POLICIES, USES AND PEDAGOGICAL CHALLENGES}

ABSTRACT:The main aim of this study was to identify and analyze who and what are the school actors using the cell phone in the school. It also set out to identify what changes have occurred and are occurring as a result of using the cell phone in the school from the point of view of discovering the changes brought about in the pedagogical activities of municipal and state schools of a medium-sized town. Using a qualitative approach, different situations of cell phone use in the school were observed. Spontaneous reports of respondents were made, registered in protocols and questionnaire were given to students. The cell phone has reached the school, so it is important to discuss ways of integrating it in a planned pedagogical manner because it is part of the culture of the subjects studying there. However, if it is to become a concrete element for professional, cultural, social and political commitment, then skilled managers, well-trained teachers and schools with adequate conditions are required.

KEY WORDS: School. Cell phone. Education. 


\section{EL TELÉFONO MÓVIL CELULAR EN LA ESCOLA: POLÍTICAS, USOS Y DESAFÍOS PEDAGÓGICOS}

RESUMEN: Este estudio tuvo como principal objetivo identificar y analizar quienes y cuales son los actores escolares que utilizan teléfonos móviles celulares en la escuela. Buscamos también identificar qué cambios ocurrieron y ocurren con el uso de los teléfonos móviles celulares en la escuela bajo la perspectiva de conocer las alteraciones provocadas en las actividades pedagógicas de las escuelas municipales y estatales en una ciudad de tamaño mediano. Bajo el enfoque cualitativo, se observaron las diferentes situaciones de uso de teléfonos celulares en la escuela, informes espontáneos de los investigadores, anotados en los protocolos de registro, y la aplicación de un cuestionario a los estudiantes. Los teléfonos celulares están en la escuela y es importante discutir formas de incorporarlos y promover usos intencionales para este contexto, puesto que es parte de la cultura de los estudiantes que allí van. Sin embargo, para que se conviertan en elementos concretos de compromiso profesional, cultural, social y político, se necesitan gestores capacitados, profesores bien entrenados y escuelas en condiciones apropiadas.

Palabras claves: Escuela. Teléfonos móviles. Educación.

\section{NOTAS}

1. A revisão sistemática refere-se a um procedimento de preparar protocolos com os termos da problemática a ser estudada e que permite fazer revisão da literatura, capturando os textos mais relevantes dos temas da pesquisa.

2. O Projeto de Lei n. 2.246 estava em discussão desde 2007. No sítio da câmara dos deputados, há o histórico da tramitação descrevendo que, em outubro de 2007, o deputado Pompeo de Mattos (PDT/RS) apresentou o projeto de lei (que foi arquivado), vedando o uso dos celulares nas escolas públicas. Esse projeto de lei foi encaminhado para a Comissão de Educação e Cultura e ficou tramitando até ser arquivado em janeiro de 2011. Em novembro de 2011, o deputado Márcio Macedo (PT/SE) reapresentou o projeto de lei com as alterações sugeridas pela Comissão de Educação e Cultura.

\section{REFERÊNCIAS}

BARROS, L. M. de. A dimensão pedagógica da comunicação. Revista de Educação do Cogeime, ano 9, n. 16, jun. 2000.

BRASIL, Câmara dos Deputados. PL 2.246/2007. Situação: arquivada na mesa diretora da Câmara dos Deputados (MESA). Disponível em: <http://www.camara.gov.br/ proposicoesWeb/fichadetramitacao?idProposicao=372564>. Acesso em: 10 jul. 2013.

. PL 2.806/2011. Proíbe o uso de aparelhos eletrônicos portáteis nas salas de aula dos estabelecimentos de educação básica e superior. Disponível em: <http:// 
www.camara.gov.br/proposicoesWeb/prop_mostrarintegra?codteor $=945034 \&$ filen ame $=P L+2806 / 2011$ > . Acesso em: 6 dez. 2012.

.PL 2.806/2011. Situação: aguardando parecer na Comissão de Educação (CE). Disponível em: <http://www.camara.gov.br/proposicoesWeb/fichadetramitacao?idP roposicao=529264>. Acesso em: 10 jul. 2013.

CARON, A. H.; CARONIA, L. Culture móbile: lês nouvelles pratiques de communication. Les Presses de I'Université de Montréal, 2005. (Tradução livre da professora da PUC-Goiás, Joana Peixoto, janeiro 2013).

DURAN, D. Letramento digital e desenvolvimento: das afirmações às interrogações. São Paulo: Hucitec, 2010.

LEITE, M. S. Entre a bola e o MP3 - novas tecnologias e diálogo intercultural no cotidiano escolar adolescente. In: CANDAU, V. (Org.). Didática - questões contemporâneas. Rio de Janeiro: Forma \& Ação, 2009.

LIBÂNEO, J. C. Adeus professor, adeus professora? Novas exigências educacionais e profissão docente. 4. ed. São Paulo: Cortez, 2000.

. Alguns aspectos da política educacional do governo Lula e sua repercussão no funcionamento das escolas. Texto de conferência proferida no XV ENCONTRO NACIONAL DE GEÓGRAFOS, realizado no período de 20 a 26 de julho de 2008, São Paulo, promovido pela Associação de Geógrafos do Brasil (AGB). Publicado nos Anais do XV ENG. Disponível em <http://www.histedbr.fae.unicamp.br/revista/edicoes/32/ art12_32.pdf>. Acesso em: 15 mar. 2012.

LÜDKE, M.; ANDRÉ, M. Pesquisa em educação: abordagens qualitativas. São Paulo: EPU, 1986.

MOURA, A. M. C. Apropriação do telemóvel como ferramenta de mediação em Mobile Learning: estudos de caso em contexto educativo. Tese (Doutorado em Ciências da Educação, na Especialidade de Tecnologia Educativa) - Universidade do Minho, Instituto de Educação, Braga, dez. 2010.

NÓVOA, A. Professores: imagens do futuro presente. Lisboa: Educa, 2009.

PRENSKY, M. Não me atrapalhe, mãe - eu estou aprendendo!; como os videogames estão preparando nossos filhos para o sucesso no século XXI - e como você pode ajudar! Tradução de Lívia Bergo. São Paulo: Phorte, 2010.

PRETTO, N. de L. O desafio de educar na era digital: educações. Revista Portuguesa de Educação, v. 24, n. 1, p. 95-118, 2011. CIEd - Universidade do Minho. Disponível em: <http://www.scielo.oces.mctes.pt/pdf/rpe/v24n1/v24n1a05.pdf>. Acesso em: 28 mar. 2012.

SANTAELLA, L. A aprendizagem ubíqua substitui a aprendizagem formal? Revista de Computação e Tecnologia da PUC-SP, FCET/PUC-SP, São Paulo, v. II, n. 1, 2010. Disponível em: <http://revistas.pucsp.br/index.php/ReCET/article/view/3852/2515>. Acesso em: 21 maio 2012. 
SOUZA e SILVA, A. de. Do ciber ao híbrido: tecnologias móveis como interfaces de espaços híbridos. In: ARAÚJO, D. C. (Org.). Imagem (ir) realidade - comunicação e cibermídia. Porto Alegre: Sulina, 2006.

TOSCHI, M. S. Comunicação Mediada por Dispositivo Indutor (CMDI): elemento novo nos processos educativos. In: LIBÂNEO, J. C.; SUANNO, M. V. R. (Orgs.). Didática e escola numa sociedade complexa. Goiânia: CEPED, 2011.

WOLTON, D. É preciso salvar a comunicação. São Paulo: Paulus, 2006.

LíviA dA Silva Neiva MarTin é mestranda em Educação, Linguagem e Tecnologias pelo Programa de Mestrado Interdisciplinar em Educação, Linguagem e Tecnologias da Universidade Estadual de Goiás. Especialista em Educação a Distância e graduada em Comunicação Social.

E-mail: livianeiva@gmail.com

MirZa SeAbra Toschi é doutora em Educação pela Universidade Metodista de Piracicaba (Unimep), com estágio de pós-doutorado na Faculdade de Educação da Universidade de Brasília (UnB). Atualmente, é docente de ensino superior da Universidade Estadual de Goiás, onde coordenou o Mestrado Interdisciplinar em Educação, Linguagem e Tecnologias da Unidade Universitária de Ciências Socioeconômicas e Humanas, no período 2012-2013. Foi coordenadora do GT Educação e Comunicação da ANPEd (2001-2002). É representante da UEG no Conselho Estadual de Educação de Goiás, compondo as Câmaras de Educação Básica, Superior e Profissional. Tem experiência na área de Educação, com ênfase em formação de professores, pesquisando sobre as tecnologias na educação.

E-mail: mirzas@brturbo.com.br 